Web Jurnal:

http://ejournal.kemenperin.go.id/jli

\title{
Aplikasi gambir (Uncaria gambir Roxb) melalui proses pencucian berulang sebagai antioksidan pada pangan berminyak
}

\section{Application of gambier (Uncaria gambier Roxb) through a repeated washing process as an antioxidant in oily foods}

\author{
F. Firdausni*, Wilsa Hermianti, dan Yulia Helmi Diza \\ Balai Riset dan Standardisasi Industri Padang \\ Jl. Raya LIK No.23 Ulu Gadut Padang, Indonesia \\ * e-mail: firdausni85@gmail.com
}

\begin{tabular}{l}
\hline INFO ARTIKEL \\
\hline Sejarah artikel: \\
Diterima: \\
18 Mei 2020 \\
Direvisi: \\
24 Juni 2020 \\
Diterbitkan: \\
29 Juni 2020
\end{tabular}

\section{Kata kunci:}

gambir;

katekin;

antioksidan;

pangan berminyak

\begin{abstract}
ABSTRAK
Gambir mengandung katekin sebagai komponen utama yang merupakan senyawa polifenol berpotensi sebagai antioksidan dan antibakteri. Antioksidan alami gambir dapat diaplikasikan pada pengolahan pangan sebagai pengganti antioksidan sintetis. Senyawa antioksidan dapat mencegah terjadinya proses oksidasi dari asam lemak pada produk yang mengandung lemak dan minyak. Pengolahan gambir melalui proses pencucian berulang dilakukan untuk menghasilkan gambir dengan katekin tinggi. Penelitian bertujuan melihat efektifitas antioksidan alami gambir murni terhadap pangan berminyak (pinyaram dan keripik singkong). Penelitian dilakukan dengan perlakuan penambahan katekin gambir pada pinyaram, kontrol (tanpa katekin gambir), katekin gambir $0,5 \mathrm{~g} / \mathrm{kg}$, $1,0 \mathrm{~g} / \mathrm{kg}, 1,5 \mathrm{~g} / \mathrm{kg}$ dan BHT $0,2 \mathrm{~g} / \mathrm{kg}$ sebagai antioksidan sintetis pembanding. Pada keripik singkong kontrol, katekin gambir $0,2 \mathrm{~g} / \mathrm{kg}, 0,4 \mathrm{~g} / \mathrm{kg}, 0,6 \mathrm{~g} / \mathrm{kg}, 0,8 \mathrm{~g} / \mathrm{kg}$ dan BHT $0,2 \mathrm{~g} / \mathrm{kg}$ sebagai antioksidan sintetis. Hasil perlakuan optimal pada pinyaram pada penggunaan katekin gambir $1,0 \mathrm{~g} / \mathrm{kg}$ dengan kadar lemak $24,5 \%$, bilangan peroksida 0,18 meq $/ \mathrm{kg}$ (1 minggu penyimpanan) dan polifenol $643 \mathrm{ppm}$. Sedangkan pada keripik singkong $0,6 \mathrm{~g} / \mathrm{kg}$ dengan kadar lemak 30,94\%, bilangan peroksida $0,29 \mathrm{meq} / \mathrm{kg}$ dan polifenol $391 \mathrm{ppm}$. Ketahanan daya simpan sampai minggu ke-2 untuk pinyaram dan minggu ke -3 untuk keripik singkong dengan organoleptik rasa disukai.
\end{abstract}

Keywords:

gambier;

catechin;

antioxidant;

oily food

\begin{abstract}
Gambir contains catechins as the main component which is a polyphenol compound that has a potential as an antioxidant and antibacterial. Natural antioxidants of gambir can be applied in food processing as a substitute for synthetic antioxidants. Antioxidant compounds can prevent the oxidation process of fatty acids in products containing fats and oils. Processing of gambier through repeated washing was carried out to produce gambier with high catechins. The research was aimed to see the effectiveness of pure gambier natural antioxidants in oily food (pinyaram and cassava chips). The study was conducted by adding gambier catechin to pinyaram, control (without gambier catechin), gambier catechin $0.5 \mathrm{~g} / \mathrm{kg}, 1.0 \mathrm{~g} / \mathrm{kg}$ ), $1.5 \mathrm{~g} / \mathrm{kg}$ and BHT $0.2 \mathrm{~g} / \mathrm{kg}$ as a comparative synthetic antioxidant. On cassava chips namely control, $0.2 \mathrm{~g} / \mathrm{kg}, 0.4 \mathrm{~g} / \mathrm{kg}, 0.6 \mathrm{~g} / \mathrm{kg}, 0.8$ $\mathrm{g} / \mathrm{kg}$ and BHT $0.2 \mathrm{~g} / \mathrm{kg}$ as synthetic antioxidants. The optimal treatment result was obtained in pinyaram with the use of gambier catechin $1.0 \mathrm{~g} / \mathrm{kg}$ with $24.5 \%$ fat content, peroxide number $0.18 \mathrm{meq} / \mathrm{kg}$ (1 week of storage) and polyphenols $643 \mathrm{ppm}$. Whereas on cassava chips $0.6 \mathrm{~g} / \mathrm{kg}$ with fat content $30.94 \%$, peroxide number $0.29 \mathrm{meq} / \mathrm{kg}$ and polyphenols $391 \mathrm{ppm}$. The storage resistance was up to second weeks for pinyaram and third weeks for cassava chips with organoleptic test was preferred.
\end{abstract}




\section{Pendahuluan}

Tanaman gambir sebagai salah satu sumber antioksidan merupakan tanaman perdu termasuk famili Rubiace yang mengandung senyawa polifenol. Polifenol merupakan senyawa turunan fenol yang mempunyai aktivitas sebagai antioksidan. Komponen utama yang terdapat pada gambir terdiri dari katekin (asam katekin), asam katekin tanat dan quercetine. Katekin memiliki rasa yang manis dan bisa berubah menjadi catechin tannat (memberikan rasa pahit) jika terjadi pemanasan yang cukup lama atau pamanasan dengan larutan bersifat basa (Muchtar et al., 2010). Pemanfaatan gambir sebagai antioksidan pangan selama ini masih belum optimal karena kurangnya pengetahuan masyarakat dalam ekstraksi gambir. Gambir digunakan untuk zat pewarna kain batik (Failisnur et al., 2017), penyamak kulit (Kasim and Mutiar, 2012), ramuan makan sirih, bahan baku pembuatan permen dalam acara adat di India dan sebagai penjernih pada industri air. Di lain pihak, gambir sangat potensial untuk diaplikasikan pada bahan pangan, diantaranya untuk keperluan memperpanjang masa simpan bahan pangan.

Salah satu antioksidan alami yaitu katekin yang merupakan senyawa polifenol yang berpotensi sebagai antioksidan dan antibakteri. Katekin paling banyak terdapat pada tanaman gambir (Uncaria gambir Roxb). Gambir kualitas super mengandung katekin 74\% (Yeni et al., 2017) sedangkan katekin pada teh sekitar 30-40\%. Katekin merupakan senyawa polifenol yang berpotensi sebagai antioksidan dan antibakteri serta aman digunakan dalam pengolahan bahan pangan. Gambir mempunyai aktivitas penangkapan radikal DPPH lebih tinggi dari BHT ((Rauf et al., 2010)

Dalam kehidupan sehari hari antioksidan mulai banyak digunakan dalam berbagai bidang yaitu pangan, bidang kesehatan dan kosmetik. Dalam bidang pangan, antioksidan alami digunakan sebagai bumbu berbagai jenis makanan dan minuman, sedangkan dalam bidang kesehatan digunakan dalam menjaga kesegaran (dibuat sebagai minuman penyegar), untuk obat tradisional dan mencegah penyakit degenerative seperti kanker atau membunuh mikroba.

Antioksidan mempunyai peran penting dalam mencegah perubahan bahan yang tidak dikehendaki dalam makanan yang mengandung lipid. Antioksidan sintetik yang paling sering digunakan adalah Propil Galat (PG), Butylated Hydroxyanisole (BHA), Butylated Hydroxytoluene (BHT) dan Tertbutyl Hydroquinone (TBHQ). Antioksidan sintetik ini dikhawatirkan dapat menimbulkan efek samping yang berbahaya bagi kesehatan manusia karena bersifat karsinogenik. Berbagai studi mengenai BHA dan BHT menunjukkan bahwa komponen ini dapat menimbulkan tumor pada hewan percobaan pada penggunaan dalam jangka panjang (Katrin and Bendra, 2015).

Kekhawatiran dengan adanya kemungkinan efek samping dari antioksidan sintetik menyebabkan antioksidan alami menjadi alternatif yang perlu dikembangkan. Antioksidan alami mampu melindungi tubuh terhadap kerusakan yang disebabkan senyawa oksigen reaktif, menghambat terjadinya penyakit, serta mampu menghambat peroksidasi lipid pada makanan. (Martiningsih et al., 2016).

Antioksidan alami merupakan suatu sistem pertahanan dalam tubuh yang berguna untuk menangkal kerusakan sel tubuh yang disebabkan oleh radikal bebas. Masalah akan muncul ketika jumlah radikal bebas lebih tinggi daripada antioksidan alami. Pada kondisi ini, tubuh memerlukan tambahan antioksidan dari luar yaitu dari bahan makanan tertentu.

Pemanfaatan gambir sebagai antioksidan dilakukan pada produk rendang menghasilkan rendahnya bilangan peroksida selama penyimpanan (Muchtar et al., 2010). Penggunaan antioksidan alami gambir pada pangan dapat dilakukan dengan tidak mempengaruhi tekstur dan rasa, sehingga perlu dilakukan pencucian berulang sebagai upaya mengilangkan pengotor dan menurunkan kadar tanin yang memberikan rasa pahit.

Untuk mendapatkan katekin yang tinggi dapat dilakukan melalui proses ekstraksi ulang gambir. Teknologi proses dilakukan berdasarkan perbedaan sifat kelarutan antara katekin dan tanin dalam air. Katekin dalam keadaan murni sulit larut dalam air dingin, namun mudah larut dalam air panas. Untuk menghilangkan rasa pahit dan kelat yang ditimbulkan oleh senyawa tanin dan meningkatkan kemampuan gambir sebagai antioksidan melalui proses ekstraksi senyawa polifenol pada kondisi tertentu menggunakan pelarut yang aman untuk dikonsumsi, tahap proses ekstraksi yang dilakukan efisien dan dapat diterapkan oleh usaha kecil menengah (Muchtar et al., 2010).

Produk makanan gorengan memiliki kandungan lemak dan minyak yang tinggi, berasal dari minyak yang diserap oleh makanan tersebut selama proses penggorengan. Minyak goreng berfungsi sebagai media penghantar panas dalam pengolahan bahan pangan. Faktor yang mempengaruhi daya serap minyak ditentukan oleh suhu, bahan pangan, bentuk, porositas produk, dan komposisi produk. Proses penggorengan dan lama penyimpanan pada produk yang berminyak akan berdampak pada mutu pangan yang dapat menurunkan tingkat penerimaan dan bahkan membahayakan kesehatan konsumen. Hal ini karena terjadinya reaksi oksidasi pada komponen bahan makanan berakibat munculnya aroma tidak sedap sehingga menurunkan penerimaan bahkan dapat merusak kesehatan (Rukmini, 2007).

Pada penelitian ini akan diaplikasikam antioksidan alami gambir pada pangan yang berminyak diantaranya kue pinyaram dan keripik ubi singkong. Pinyaram merupakan pangan gorengan khas dari Minangkabau yang dijumpai pada acara adat. Produk yang sama juga ditemukan sebagai makanan khas Betawi yang dinamakan kue cucur. Pinyaram dengan bentuk bulat, pipih dengan warna coklat, hitam dan hijau dengan bahan dasar tepung ketan, gula pasir atau gula aren ditambah dengan bahan tambahan lainnya diaduk dan digoreng dengan minyak goreng.

Sedangkan keripik ubi singkong juga merupakan makanan khas yang sering dijadikan sebagai buah tangan. Keripik singkong adalah sejenis pangan ringan berupa irisan tipis dari buah singkong digemari kalangan masyarakat karena sifatnya yang renyah, gurih, tersedia dalam aneka rasa seperti asin, pedas dan manis. Keripik 
singkong rasa pedas yang lebih dikenal dengan keripik balado sangat digemari konsumen.

Penelitian bertujuan untuk melihat pengaruh penambahan katekin gambir sebagai antioksidan alami terhadap mutu pangan gorengan. Penambahan katekin dilakukan terhadap minyak yang digunakan sebagai media penggorengan. Penambahan dengan konsentrasi yang berbeda pada masing masing produk hal ini dilakukan untuk meminimalisasi efek warna dan rasa produk. Sebagai pembanding digunakan antioksidan sintetik BHT dengan pemakaian sesuai dengan aturan Badan Pengawas Obat dan Makanan Republik Indonesia (BPOM RI).

\section{Metode}

Penelitian dilaksanakan di Balai Riset dan Standardisasi Industri Padang. Bahan-bahan yang digunakan adalah gambir yang berasal dari pengrajin Kapur IX Kabupaten Lima Puluh Kota, aquades, bahanbahan untuk keripik ubi singkong yaitu ubi singkong, minyak goreng. Bahan-bahan untuk pinyaram diantaranya tepung ketan, gula aren, gula pasir, dan antioksidan BHT. Bahan kimia untuk pengujian yaitu metanol, larutan 1,1 diphenyl-2-picrylhydrazyl hydrate (DPPH), etanol 96\%, KI jenuh, thiosulfat, khloroform, butil hidroksi toluen, natrium karbonat, asam galat, dimetil sulfooksida (DMSO)

Peralatan yang digunakan antara lain saringan, neraca, peralatan memasak, sendok pengaduk, peralatan gelas, dan alat-alat untuk pengujian rotary evaporator, buret, erlenmeyer asah, botol maserasi, alat blansir, cawan krus, tanur, gelas ukur, gelas piala, neraca analitik, moisture balance dan peralatan pengujian lainnya.

\subsection{Pemurnian gambir}

Proses pemurnian gambir dilakukan untuk mendapatkan gambir murni dengan katekin tinggi (Muchtar et al., 2010). Gambir yang merupakan hasil ekstraksi dari daun tanaman gambir (Uncaria gambir Roxb) didapatkan di pasaran yang dikenal dengan gambir asalan. Gambir asalan kemudian dibersihkan dari kotoran dan dicuci ulang untuk mendapatkan katekin tinggi dan menghilangkan pengotor. Untuk menghilangkan rasa pahit atau kelat yang ditimbulkan oleh senyawa tanin pada gambir sebagai antioksidan dilakukan proses ekstraksi senyawa polifenol dengan menggunakan pelarut yang aman untuk dikonsumsi. Tahapan proses ekstraksi dilakukan sesuai dengan (Muchtar et al., 2010) dan (Aditya and Ariyanti, 2016).

Gambir dihaluskan dan diayak dengan saringan 100 mesh, kemudian serbuk gambir dilarutkan dengan akuades (1:8) pada suhu $\pm 70^{\circ} \mathrm{C}$ diaduk agar semua komponen dapat larut air dan disaring dengan saringan 100 mesh. Hasil saringan gambir selanjutnya dicuci lagi dengan akuades secara berulang, proses rekristalisasi ini dilakukan untuk menghilangkan komponen yang bukan katekin. Dilanjutkan dengan pengeringan pada suhu $40^{\circ} \mathrm{C}$ dengan kelembaban rendah selama 15-24 jam, disaring sehingga diperoleh konsentrat polifenol gambir berupa tepung dengan warna putih kekuningan.

\subsection{Aplikasi katekin gambir pada pinyaram}

Dilakukan penambahan katekin gambir pada pangan berminyak sebagai antioksidan alami dengan tujuan untuk menghambat proses oksidasi sehingga menambah daya simpan produk. Katekin gambir hasil pencucian ulang diaplikasikan terhadap pangan berminyak (pinyaram dan keripik singkong). Untuk pinyaram penambahan langsung ke adonan untuk selanjutnya digoreng. Perlakuan aplikasi katekin gambir dalam pembuatan pinyaram kontrol (tanpa katekin gambir), katekin gambir $0,5 \mathrm{~g} / \mathrm{kg} ; 1,0 \mathrm{~g} / \mathrm{kg} ; 1,5 \mathrm{~g} / \mathrm{kg} ;$ BHT sebagai standar $0,2 \mathrm{~g} / \mathrm{kg}$.

\subsection{Aplikasi katekin gambir pada keripik singkong}

Dilakukan penambahan katekin gambir hasil pencucian ulang terhadap pangan keripik singkong. Penambahan dilakukan ke dalam minyak goreng sebagai media penggorengan keripik singkong Perlakuan penambahan katekin gambir pada pembuatan keripik singkong kontrol (tanpa katekin gambir), katekin gambir $0,2 \mathrm{~g} / \mathrm{kg} ; 0,4 \mathrm{~g} / \mathrm{kg} ; 0,6 \mathrm{~g} / \mathrm{kg} ; 0,8 \mathrm{~g} / \mathrm{kg}$, dan BHT 0,2 g/kg.

\subsection{Pengujian dan analisis}

Pengujian dilakukan pada gambir hasil pemurnian berulang terhadap kadar katekin, kadar tanin, total fenol, dan antioksidan metoda DPPH. Katekin gambir yang digunakan sebagai antioksidan pengolahan pangan pinyaram dan keripik melalui penambahan pada minyak sebagai media penggorengan dan dilakukan pengujian berdasarkan uji kimia, fisik dan uji organoleptik.

\subsubsection{Penentuan kadar katekin}

Pembuatan bahan baku pembanding dengan mengeringkan katekin standar di dalam oven pada temperatur $105^{\circ} \mathrm{C}$ sampai bobot konstan. Ditimbang 50 mg dimasukkan ke dalam labu $50 \mathrm{~mL}$, dilarutkan dengan etil asetat. Larutan dihomogenkan dengan penangas ultrasonik selama 5 menit. Sebanyak $2 \mathrm{~mL}$ larutan dimasukkan ke dalam erlemeyer bertutup $100 \mathrm{~mL}$ dan ditambah etil asetat sebanyak $50 \mathrm{~mL}$ dan dihomogenkan lagi dengan penangas ultrasonik selama 5 menit. Kemudian pembuatan larutan sampel yaitu gambir dihaluskan dan diratakan di atas kaca arloji atau cawan petri, dikeringkan di dalam oven pada temperatur $105^{\circ} \mathrm{C}$ sampai bobot konstan. Ditimbang $50 \mathrm{mg}$ ekstrak kering, dimasukkan dalam labu $50 \mathrm{~mL}$, dilarutkan dalam etil asetat dan dihomogenkan dengan penangas ultrasonik selama 5 menit, kemudian disaring. Sebanyak $2 \mathrm{ml}$ filtrat dimasukkan ke dalam erlenmeyer bertutup $100 \mathrm{~mL}$, ditambahkan etil asetat sebanyak $50 \mathrm{~mL}$, dan dihomogenkan lagi dengan penangas ultrasonik selama 5 menit. Pengukuran absorban larutan blanko (etil asetat), larutan katekin standar dan larutan sampel menggunakan alat spektrofotometer ultraviolet pada panjang gelombang $279 \mathrm{~nm}$ dan $300 \mathrm{~nm}$. Absorban sampel pada $300 \mathrm{~nm}$ tidak lebih dari 0,03. Perhitungan dilakukan dengan persamaan (1). 


$$
\% \text { Katekin }=\frac{\text { As } 279}{\text { Ap } 279} \times \frac{\text { Ws }}{W} \times 100 \%
$$

As 279 : absorban sampel pada $279 \mathrm{~nm}$

Ap 279 : absorban katekin standar pada $279 \mathrm{~nm}$

Ws : berat katekin standar

W : berat sampel

\subsubsection{Penentuan total fenol}

Kandungan total fenol ditentukan dengan prosedur Folin-Ciocalteu yang dimodifikasi sesuai yang dilakukan oleh (Chaovanalikit and Wrolstad, 2004) Sebanyak $0,5 \mathrm{~mL}$ sampel ekstrak cair (1 mg bubuk gambir dilarutkan dalam $10 \mathrm{~mL}$ aquadest) atau satu seri standar asam galat $(0,40,80,120,160$, dan 200 ppm) dicampur dengan 0,5 mL Reagen FolinCiocalteu (Sigma Chemical Co., St. Lois, Mo., U.S.A.) dan ditambah 7,5 $\mathrm{mL}$ deionized water. Campuran dibiarkan pada suhu kamar selama 10 menit sebelum penambahan 1,5 mL sodium karbonat $20 \%(\mathrm{w} / \mathrm{v})$. Campuran selanjutnya dipanaskan pada suhu $40^{\circ} \mathrm{C}$ dalam penangas air selama 20 menit. Setelah pemanasan, campuran secepatnya didinginkan dalam lemari pendingin sebelum pengukuran absorbansi pada panjang gelombang 755 nm. Penyiapan blanko dilakukan dengan menggunakan aquades dan reagen yang sama.

\subsubsection{Aktifitas antioksidan metoda DPPH}

Sebanyak $1 \mathrm{ml}$ larutan DPPH 0,0010 M ditambahkan $4 \mathrm{ml}$ larutan ekstrak (untuk kontrol ekstrak digantikan metanol). Larutan dikocok sampai homogen dan dibiarkan selama 30 menit. Kemudian absorbansinya diukur terhadap metanol pada panjang gelombang 517 $\mathrm{nm}$ menggunakan spektrofotometer UV-Visible (BrandWilliams et al., 1995). Pengujian ini juga dilakukan pengukuran terhadap blangko (larutan DPPH yang tidak menganding bahan uji) serta kontrol positif kuersetin. Aktivitas penangkap radikal DPPH (\%) dihitung dengan rumus (2).

$$
\text { Aktivitas }=\frac{\text { A blangko }- \text { A sampel }}{\text { A blangko }} \times 100 \%
$$

\section{Keterangan:}

A blangko: nilai absorbansi kontrol

A sampel : nilai absorbansi sampel

Data aktivitas antioksidan dianalisis dan masing masing dihitung nilai IC 50 melalui analisis probit.

\subsubsection{Uji organoleptik tingkat kesukaan}

Pengujian tingkat kesukaan dilakukan terhadap produk pinyaram dan keripik singkong yang telah di tambahkan katekin gambir sesuai perlakuan dengan pembanding antioksidan sintetis BHT. Uji organoleptik oleh panelis yang berkompeten terhadap rasa, warna dan tekstur. Penilaian sesuai dengan SNI. 01-2346-2006 (Petunjuk Pengujian Organoleptik atau Sensori). Penilaian organoleptik digunakan untuk menilai mutu dalam industri pangan dan industri hasil pertanian lainnya. Penilaian ini dapat memberi hasil penilaian yang langsung dirasakan konsumen. Penilaian dengan indera bahkan melebihi ketelitian alat yang paling sensitif (Lamusu, 2018)

Uji organoleptik dilakukan untuk mengetahui tingkat kesukaan konsumen terhadap warna, rasa, dan aroma pada pinyaram dan keripik singkong. Metode pengujian kesukaan yang dilakukan adalah scoring, dengan panelis sebanyak 20 orang. Pengujian ini dilakukan dengan memberi kode secara acak pada sampel yang disajikan agar tidak menimbulkan penafsiran tertentu oleh panelis. Kriteria penilaian uji organoleptik pada Tabel 1.

Tabel 1

Skala penilaian uji organoleptik

\begin{tabular}{llll}
\hline $\begin{array}{l}\text { Warna vs } \\
\text { aslinya }\end{array}$ & Rasa & Aroma & $\begin{array}{l}\text { Skala } \\
\text { numerik }\end{array}$ \\
\hline sangat sama & sangat suka & sangat suka & 5 \\
sama & suka & suka & 4 \\
kurang sama & kurang suka & kurang suka & 3 \\
tidak sama & tidak suka & tidak suka & 2 \\
sangat & sangat tidak & sangat tidak & 1 \\
berbeda & suka & suka & \\
\hline
\end{tabular}

\section{Hasil dan pembahasan}

\subsection{Karakteristik katekin gambir hasil pemurnian}

Hasil pengamatan secara fisiologis dan kimia katekin gambir setelah dilakukan pencucian ulang sebanyak 4 kali seperti pada Tabel 2.

Tabel 2

Karakteristik katekin gambir hasil pencucian ulang

\begin{tabular}{ll}
\hline Parameter & Hasil pengujian / pengamatan \\
\hline Rendemen (\%) & $35,2 \pm 0,49$ \\
Katekin (\%) & $75,32 \pm 2,01$ \\
Kadar air (\%) & $11,12 \pm 1,58$ \\
Karakteristik & $\begin{array}{l}\text { serbuk halus warna putih } \\
\text { kekuningan }\end{array}$ \\
\hline
\end{tabular}

Gambir yang dihasilkan setelah pencucian ulang selanjutnya dikatakan katekin gambir berupa serbuk halus dengan warna putih kekuningan, sedangkan gambir asalan bewarna coklat sampai kehitaman karena taninnya yang tinggi. Kadar tanin yang tinggi mempengaruhi warna gambir (Yeni et al., 2017).

Cara Pengolahan dan asal bahan baku yang berbeda akan menghasilkan rendemen yang diperoleh. Rendemen yang dihasilkan pada penelitian $35,2 \%$ lebih tinggi dari penelitian yang dilakukan oleh (Muchtar et al., 2010) yang menghasilkan katekin pada 4 kali pencucian $33,1 \%$. Perolehan rendemen dalam menghasilkan katekin gambir dipengaruhi oleh bahan baku yang digunakan, jumlah air yang ditambahkan, pengadukan atau homogenitas dan besarnya saringan yang digunakan. Untuk mendapatkan katekin dari gambir asalan, dipengaruhi oleh beberapa faktor diantaranya 
bahan baku, teknologi proses ekstraksi ulang, pelarut dan peralatan yang digunakan (Yeni et al., 2017).

Katekin yang dihasilkan pada penelitian ini adalah $75,32 \%$. Hal ini sesuai dengan penelitian (Yeni et al., 2017) yang menyatakan pemurnian gambir asalan melalui ekstraksi berulang dengan air dapat menurunkan kadar tanin (24\% sampai 2,4\%) dan meningkatkan kadar katekin (40\% sampai 74\%). Pencucian berulang menyebabkan terjadinya peningkatan kadar katekin dan penurunan kadar tanin, karena senyawa katekin larut baik dengan air panas dan tidak larut dalam air dingin. Peningkatan frekuensi pencucian akan menyebabkan peningkatan kadar katekin (Muchtar et al., 2010). Proses penyaringan menggunakan saringan dimaksudkan untuk memperluas kontak permukaan bahan dengan pelarut.

Gambir asalan bewarna gelap disebabkan kadar tanin yang tinggi. Kadar tanin yang tinggi berpengaruh terhadap warna hasil ekstrak yang dihasilkan. Tanin yang berwarna coklat sampai kehitaman akan menyulitkan dalam proses pemurnian katekin. Untuk mendapatkan kadar katekin yang tinggi dari ekstrak, kandungan tanin gambir asalan diharapkan dalam jumlah kecil (Yeni et al., 2017).

Gambir hasil pencucian ulang dengan kadar air rendah 11,12\%. Kadar air dipengaruhi oleh sistem pengeringan dan kondisi lingkungan yang sesuai. Berdasarkan hasil penelitian yang dilakukan (Yeni et al., 2017) proses pencucian gambir asalan dengan cara perebusan dan menggunakan peralatan aluminium dengan kadar air 14,84\%. Kadar air yang rendah dapat meningkatkan daya simpan produk. Gambir murni berupa tepung sehingga lebih mudah dimanfaatkan oleh industri dan produk farmasi. Kadar air gambir hasil pencucian ulang memenuhi persyaratan Farmakope Obat Herbal dengan kadar air $(<14 \%)$ (Departemen Kesehatan RI, 2000).

\subsection{Aktivitas antioksidan katekin gambir}

Aktivitas antioksidan katekin gambir dapat dinyatakan dalam persentase inhibisi terhadap radikal bebas DPPH, yang didapatkan dari perbedaan serapan antara absorban sampel yang diukur dengan spektrofotometer UV-Vis. Besarnya aktivitas antioksidan ditandai dengan nilai IC ${ }_{50}$ konsentrasi yang dibutuhkan dalam menghambat $50 \%$ radikal bebas DPPH. Hasil analisis menunjukkan gambir hasil pemurnian dengan 4 kali pencucian ulang dengan mempunyai meredam radikal bebas DPPH dengan IC 50 $29,32 \mu \mathrm{g} / \mathrm{ml}$ lebih kecil dari standar vitamin C 4,63 $\mu \mathrm{g} / \mathrm{ml}$, ini menunjukkan aktivitas antioksidan kuat dengan nlai IC50 $<50 \mu \mathrm{g} / \mathrm{ml}$. Semakin kecil nilai IC 50 maka semakin kuat aktivitas hambatan antioksidan (Regina et al., 2008).

\subsection{Aplikasi katekin gambir pada produk pangan}

Katekin gambir yang telah dimurnikan diaplikasikan pemakaiannya dalam pembuatan produk pangan pinyaram dan keripik singkong berupa produk makanan yang digoreng atau menggunakan minyak goreng sebagai media pemasakan. Pengujian dilakukan untuk melihat kemampuannya dalam menghambat proses oksidasi melalui parameter bilangan peroksida selama penyimpanan, kemudian dibandingkan dengan kontrol tanpa penambahan katekin gambir. Sebagai bahan pembanding digunakan antioksidan sintetis yang biasa digunakan yaitu BHT (Butylatedhydroxy Toluene.) dengan standar pemakaian maksimal bahan tambahan pangan sesuai Peraturan Badan Pengawas Obat dan Makanan.

\subsubsection{Pinyaram}

Pinyaram merupakan kue tradisional Sumatera Barat dengan bahan baku utama dari tepung ketan, gula aren, garam dan air yang diadon lalu digoreng dengan minyak panas. Makanan ini sering ditemui pada acara acara adat. Karena proses penggorengan maka pinyaram akan cepat teroksidasi oleh udara luar yang menyebakan rasa tengik.

Tabel 3.

Kadar lemak, bilangan peroksida, polifenol produk pinyaram

\begin{tabular}{lllll}
\hline Pinyaram & $\begin{array}{l}\text { Lemak } \\
(\%)\end{array}$ & $\begin{array}{l}\text { Bilangan } \\
\text { peroksida awal }\end{array}$ & $\begin{array}{l}\text { Bilangan peroksida } \\
\text { 2 minggu }(\mathrm{meq} / \mathrm{kg})\end{array}$ & $\begin{array}{l}\text { Polifenol } \\
(\mathrm{mg} \text { SAG/g) }\end{array}$ \\
\hline kontrol & $27,51 \pm 0,99$ & TT & 0,32 & 0,217 \\
katekin gambir $0,5 \mathrm{~g} / \mathrm{kg}$ & $27,76 \pm 1,60$ & TT & 0,22 & 0,326 \\
Katekin gambir $1,0 \mathrm{~g} / \mathrm{kg}$ & $24,50 \pm 2,10$ & TT & 0,18 & 0,643 \\
Katekin gambir $1,5 \mathrm{~g} / \mathrm{kg}$ & $31,46 \pm 1,94$ & TT & 0,15 & 0,721 \\
BHT 0,2 g/kg & $33,52 \pm 0,58$ & TT & 0,11 & 0,949 \\
\hline
\end{tabular}

TT : Tidak Terdeteksi

Berdasarakan hasil analisis lemak kue pinyaram setelah perlakuan penambahan gambir murni pada adonan bahan berbeda tidak nyata dengan kontrol yaitu $19,31 \%$ - 37,76\%. Tingginya kandungan lemak berdasarkan penyerapan minyak pada waktu penggorengan. Hal ini dapat disebabkan oleh sifat dari bahan baku dan penyerapan lemak serta suhu pemanasan. Lemak merupakan sumber energi tubuh selain protein dan karbohidrat, dimana $1 \mathrm{~g}$ lemak dapat menghasilkan $9 \mathrm{kkal}$, sedangkan karbohidrat dan protein hanya menghasilkan $4 \mathrm{kkal}$ (Khairunnisa et al., 2019). Kadar lemak pinyaram pada penambahan gambir 1,0\% lebih rendah dari pemakaian BHT sebagai antioksidan sintetis pembanding. Hal ini dipengaruhi oleh sifat BHT yang larut minyak sehingga terhitung sebagai lemak. Pada penambahan gambir murni yang larut dalam air 
sehingga dapat menyebabkan terjadinya hidrolisis. Reaksi hidrolisis ini akan memecah sebagian lemak menjadi gliserol, dan asam lemak bebas. Sebagian asam lemak bebas dapat menguap atau terurai sehingga tidak terukur sebagai lemak, dan menurunkan kadar lemak .

Bilangan peroksida pada awal penyimpanan produk pinyaram tidak terdeteksi. Bilangan peroksida adalah indeks jumlah lemak atau minyak yang telah mengalami oksidasi. Angka peroksida sangat penting untuk identifikasi tingkat oksidasi minyak. Minyak yang mengandung asam-asam lemak tidak jenuh dapat teroksidasi oleh oksigen yang menghasilkan suatu senyawa peroksida. Produk reaksi oksidasi asam lemak tak jenuh yang dapat dijadikan indikator tingkat oksidasi adalah senyawa peroksida dan aldehid (Aminah, 2010).

Pada 2 minggu penyimpanan kue pinyaram telah menunjukkan adanya bilangan peroksida. Bilangan peroksida terendah pada penambahan gambir murni 1,5 $\mathrm{g} / \mathrm{kg}$ dengan nilai $0,15 \mathrm{meq} / \mathrm{kg}$ tetapi masih lebih besar dari standar BHT yaitu $0,11 \mathrm{meq} / \mathrm{kg}$. Apabila dibandingkan dengan kontrol atau tanpa penambahan maka penambahan gambir murni dapat menekan angka peroksida pada pinyaram.

Hasil analisis terhadap polifenol menunjukkan semakin tinggi persentase penambahan maka semakin tinggi kadar polifenol, tetapi masih rendah dibandingkan dengan penambahan BHT seperti pada Tabel 3 . Polifenol sebagai metabolit sekunder merupakan senyawa turunan fenol yang mempunyai fungsi sebagai antibakteri dan antioksidan. Polifenol bekerja sebagai penangkap radikal bebas (Kresnawaty and Zainuddin, 2009).

\subsubsection{Keripik singkong}

Hasil analisis keripik singkong setelah penambahan gambir murni pada minyak sebagai media penggorengan seperti terlihat pada Tabel 4. Kadar lemak keripik singkong berbeda pada masing masing perlakukan, namun tidak menunjukkan perbedaan yang signifikan. Penambahan gambir murni tidak berpengaruh terhadap lemak. Hal ini dapat dilihat bila dibandingkan dengan kontrol tanpa penambahan gambir murni, kadar lemak lebih rendah dari lemak dengan gambir murni $0,2 \mathrm{~g} / \mathrm{kg}$. Hal ini disebabkan karena katekin susah larut dalam lemak tetapi larut dalam air, sehingga penambahan secara langsung pada minyak sewaktu penggorengan tidak mempengaruhi kadar lemak. Kelemahan penggunaan senyawa alami dari tanaman adalah kelarutannya yang rendah dalam lemak (Kresnawaty and Zainuddin, 2009).

Tabel 4.

Kadar lemak, bilangan peroksida dan polifenol produk keripik singkong

\begin{tabular}{|c|c|c|c|c|}
\hline Keripik Singkong & Lemak & $\begin{array}{l}\text { Bilangan } \\
\text { peroksida awal }\end{array}$ & $\begin{array}{l}\text { Bilangan Peroksida } 3 \\
\text { minggu }(\mathrm{meq} / \mathrm{kg})\end{array}$ & $\begin{array}{l}\text { Polifenol } \\
\text { (mg SAG/g) }\end{array}$ \\
\hline Kontrol & $23,52 \pm 1,26$ & TT & 0,30 & 0,185 \\
\hline Katekin gambir $0,2 \mathrm{~g} / \mathrm{kg}$ & $25,02 \pm 0,72$ & TT & 0,39 & 0,195 \\
\hline Katekin gambir $0,4 \mathrm{~g} / \mathrm{kg}$ & $25,24 \pm 1,22$ & TT & 0,38 & 0,188 \\
\hline Katekin gambir $0,6 \mathrm{~g} / \mathrm{kg}$ & $30,94 \pm 0,93$ & TT & 0,29 & 0,391 \\
\hline Katekin gambir $0,8 \mathrm{~g} / \mathrm{kg}$ & $22,12 \pm 0,80$ & TT & 0,26 & 0,589 \\
\hline BHT $0,2 \% \mathrm{~g} / \mathrm{kg}$ & $32,78 \pm 0,63$ & TT & TT & 0,635 \\
\hline
\end{tabular}

TT; Tidak Terdeteksi

Kadar lemak pada penggunaan BHT lebih tinggi dibandingkan dengan perlakuan. Hal ini disebabkan karena BHT merupakan antioksidan larut lemak sehingga pada pengujian terhitung sebagai lemak sedangkan gambir larut air. Reaksi hidrolisis akan memecah sebagian lemak menjadi gliserol, dan asam lemak bebas. Sebagian asam lemak bebas dapat menguap atau terurai sehingga tidak terukur sebagai lemak, dan menurunkan kadar lemak (Arpi, 2014).

Tingginya bilangan peroksida mengindikasikan kerusakan pangan. Pada awal penyimpanan keripik ubi dengan bilangan peroksida yang tidak terdeteksi, menunjukkan keripik singkong layak dikonsumsi untuk semua perlakuan. Penyimpanan selama 3 minggu menghasilkan bilangan peroksida yang bervariasi pada perlakuan tetapi tetap tidak ternyata pada antioksidan sintetis BHT 0,2 g/kg. Bilangan peroksida merupakan nilai untuk menentukan derajat kerusakan minyak atau lemak. Asam lemak tidak jenuh dapat mengikat oksigen pada ikatan rangkapnya sehingga membentuk peroksida. Peroksida yang dihasilkan bersifat tidak stabil dan akan mudah mengalami dekomposisi oleh proses isomerasi, dan akhirnya menghasilkan persenyawaan dengan berat molekul lebih rendah, aldehid dan keton serta asam-asam lemak bebas yang mudah (Gulcin, 2012).

Bilangan peroksida terendah pada perlakuan penambahan gambir murni $0,8 \mathrm{~g} / \mathrm{kg}$, sedangkan kontrol tanpa penambahan tidak berbeda nyata dengan perlakuan penambahan gambir murni. Hal ini dapat disimpulkan bahwa pemakaian gambir murni pada minyak dalam penggorengan keripik singkong tidak berpengaruh terhadap bilangan peroksida. Hal ini hampir sama seperti pada peningkatan bilangan peroksida, yaitu diduga karena kurang efektifnya asam askorbat dalam menghambat terjadinya reaksi oksidasi asam lemak, terutama asam lemak tak jenuh, sehingga dapat meningkatkan bilangan peroksida.

Pengujian polifenol bertujuan untuk menentukan total senyawa fenolik yang terkandung pada sampel dan bila tinggi menunjukkan aktivitas antioksidan yang tinggi pula (Hermawan et al., 2018). Polifenol tertinggi pada pemakaian gambir murni $0,8 \mathrm{~g} / \mathrm{kg}$ yaitu $589 \mathrm{ppm}$, 
namun masih rendah dari pemakaian BHT 0,2 g/kg. Polifenol meningkat seiring dengan peningkatan penambahan gambir murni. Hal ini mengindikasikan bahwa adanya aktivitas antioksidan gambir pada produk keripik singkong.

\subsection{Pengujian organoleptik}

Uji organoleptik dilakukan oleh panelis terhadap warna, rasa, aroma dan tekstur produk pinyaram dan keripik singkong. Pengujian organoleptik merupakan teknik penilaian menggunakan panca indera manusia. Uji organoleptik merupakan tingkat kesukaan berperan dalam pengembangan kualitas produk pangan. Hasil rata -rata penilaian organoleptik oleh panelis terhadap pinyaram dan keripik singkong seperti pada Gambar 1 dan Gambar 2.

\subsubsection{Aroma}

Hasil penilaian terhadap aroma, warna, rasa dan tekstur pinyaram seperti pada Gambar 1. Nilai rata-rata aroma disukai dengan skor 2,9-3,45. Pemakaian gambir murni sesuai perlakuan tidak mempengaruhi penilaian terhadap aroma, begitu juga dengan pemakaian BHT 0,2 $\mathrm{g} / \mathrm{kg}$. Aroma pinyaram dipengaruhi oleh komposisi bahan yang digunakan dan proses pengolahan. Aroma pada proses penggorengan dipengaruhi juga oleh minyak yang digunakan sebagai media penggorengan. Reaksi oksidasi selama proses penggorengan menghasilkan komponen-komponen yang mempengaruhi aroma minyak. Minyak selama penggorengan akan terserap ke dalam bahan.

Sedangkan penilaian organoleptik aroma keripik singkong (Gambar 2) terlihat penambahan gambir tidak berpengaruh pada aroma keripik dan disukai panelis. Timbulnya aroma makanan disebabkan oleh terbentuknya senyawa yang mudah menguap sebagai akibat atau reaksi karena pekerjaan enzim atau dapat juga terbentuk tanpa bantuan reaksi enzim. Kemudian komponen aroma sangat berkaitan dengan konsentrasi komponen aroma.Faktor lain adalah interaksi alami antara komponen aroma dan komponen nutrisi dalam makan tersebut seperti karbohidrat, protein dan lemak serta penerimaan konsumen yang sangat relatif.

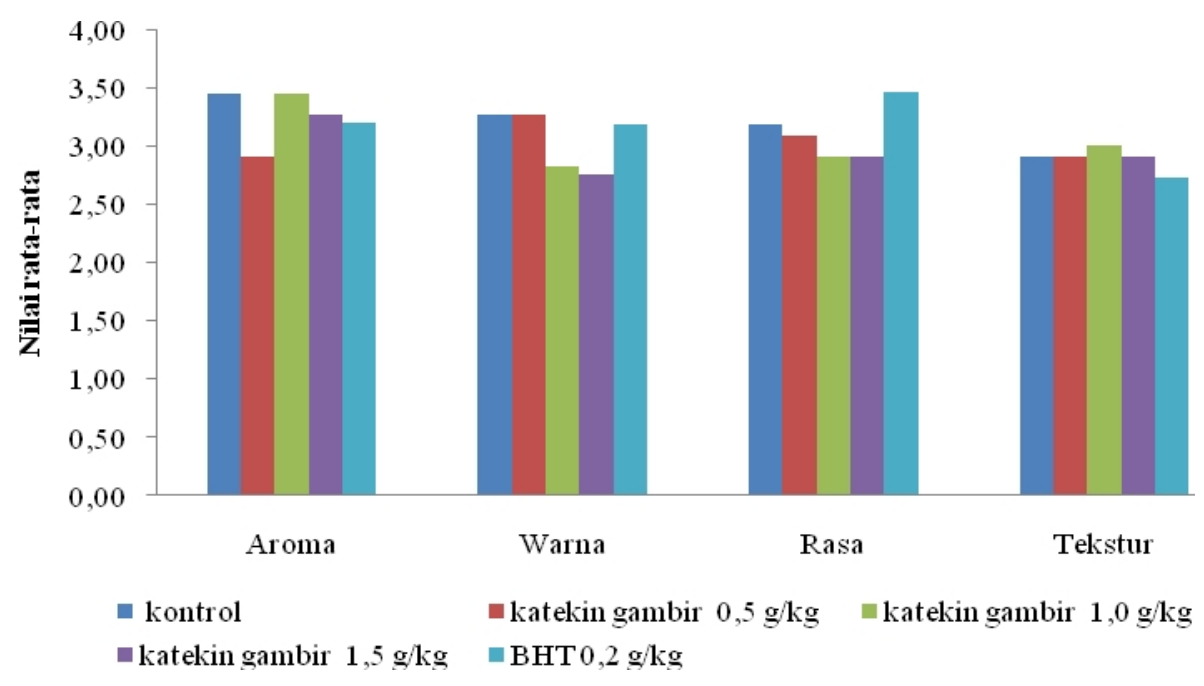

Gambar 1. Grafik uji organoleptik pinyaram dengan perlakuan penambahan katekin gambir sebagai antioksidan. Skor sensoris hedonik nilai 1( tidak suka); 2 ( agak suka); 3 (suka); 4 (sangat suka)

\subsubsection{Warna}

Penilaian terhadap warna pinyaram menunjukkan bahwa pada penambahan $0,5 \mathrm{~g} / \mathrm{kg}$ dengan tingkat kesukaannya sama dengan kontrol (tanpa penambahan) (Gambar 1), hal ini menyatakan bahwa penambahan 0,5 $\mathrm{g} / \mathrm{kg}$ tidak berpengaruh terhadap tingkat kesukaan konsumen yaitu disukai sampai sangat suka. Pada peningkatan persentase penambahan menghasilkan penurunan penilaian warna produk, tetapi masih disukai panelis (skore 2,76 dan 2,82).

Berbeda dengan keripik singkong (Gambar 2) semakin tinggi persentase penambahan gambir maka menyebabkan penurunan terhadap tingkat kesukaan warna. Warna keripik singkong menjadi gelap pada penambahan yang tinggi, Hal ini disebabkan terjadinya reaksi pada waktu penggorengan, dimana penggorengan mengakibatkan terjadinya reaksi Maillard yang menghasilkan warna kecoklatan. Katekin gambir pada suhu tinggi akan berubah menjadi tanin dan mewarna gelap. Warna merupakan parameter organoleptik yang paling pertama dalam penyajian. Warna merupakan kesan pertama karena menggunakan indera penglihatan, warna yang menarik akan mengundang selera panelis (Lamusu, 2018)

\subsubsection{Rasa}

Organoleptik rasa pinyaram menunjukkan nilai dengan kriteria suka sampai sangat suka. Penambahan katekin gambir tidak berpengaruh terhadap rasa. Rasa pinyaram yang khas dapat menutupi penambahan gambir pada adonan pinyaram dalam batas penggunaan yang kecil $0,5 \mathrm{~g} / \mathrm{kg}$, tetapi pada penambahan $1,0 \mathrm{~g} / \mathrm{kg}$ dan 1,5 
$\mathrm{g} / \mathrm{kg}$ gambir murni menunjukkan penurunan tingkat kesukaan rasa. Hal yang sama pada penelitian penambahan gambir $0,015 \% \quad(0,15 \quad \mathrm{~g} / \mathrm{kg})$ dalam pembuatan cake bengkuang menghasilkan rasa yang disukai panelis (Kamsina and Firdausni, 2018).

Pengamatan rasa keripik singkong dimana perlakuan penambahan gambir dapat menurunkan nilai rasa pada penambahan yang tinggi sedangkan penambahan dalam jumlah kecil $0,4 \mathrm{~g} / \mathrm{kg}$ disukai panelis, hal yang sama pada penambahan gambir $0,02 \%(0,2 \mathrm{~g} / \mathrm{kg})$ dalam pembuatan cake bengkuang menghasilkan rasa disukai (Kamsina and Firdausni, 2018).

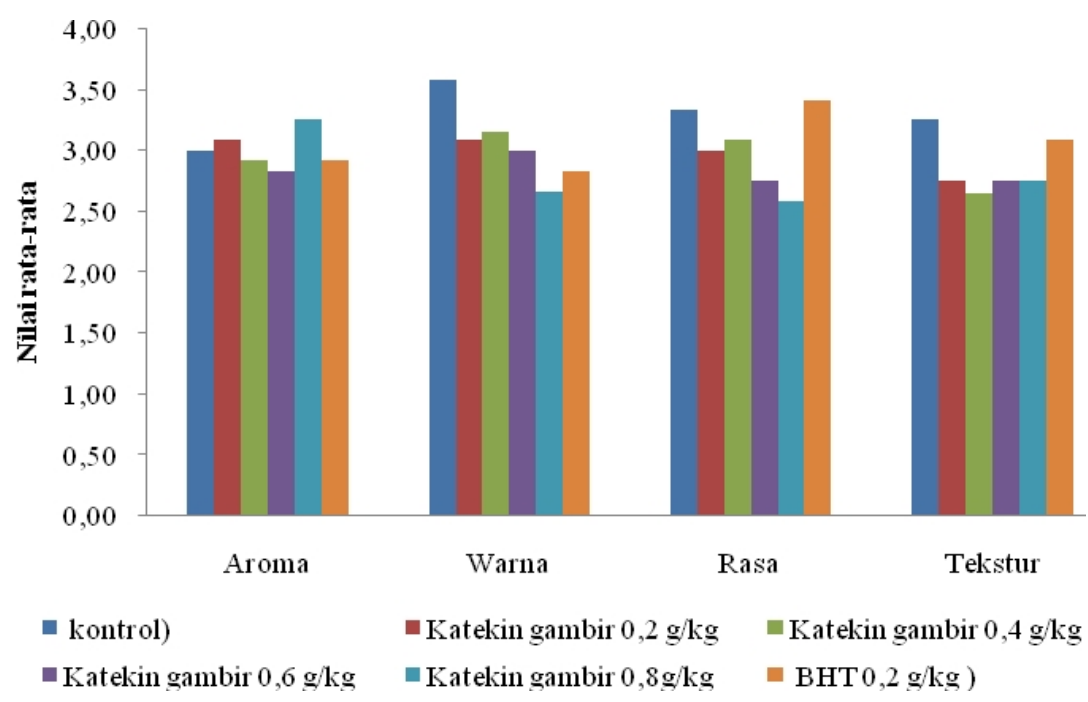

Gambar 2. Grafik uji organoleptik keripik singkong dengan perlakuan penambahan katekin gambir sebagai antioksidan. Skor sensoris hedonik nilai 1( tidak suka); 2 ( agak suka); 3 (suka); 4 (sangat suka)

\subsubsection{Tekstur}

Hasil organoleptik tekstur pinyaram menunjukkan tidak ada pengaruh penambahan gambir terhadap tekstur, dan disukai (Gambar 1), begitu juga dengan tekstur pada keripik singkong. Penambahan gambir murni tidak berpengaruh terhadap tekstur pinyaram dengan nilai rata-rata (2,92-3,00 disukai) dan keripik singkong dengan nilai rata-rata $(2,65-2,75$ disukai). Tekstur suatu bahan akan mempengaruhi cita rasa yang ditimbulkan oleh cita rasa bahan pangan tersebut (Lamusu, 2018)

\section{Kesimpulan}

Hasil penelitian dapat disimpulkan bahwa pencucian berulang dengan menggunakan air dapat meningkatkan konsentrasi katekin pada gambir, mendapatkan konsentrasi polifenol yang cukup tinggi dengan aktivitas antioksidan $\mathrm{IC}_{50}$ yang baik. Perlakuan penambahan gambir murni pada pangan gorengan pinyaram dan keripik singkong berpengaruh terhadap penyimpanan. Pemakaian optimal pada pangan pinyaram dengan penambahan gambir $1,0 \mathrm{~g} / \mathrm{kg}$ dengan kadar lemak $24,50 \%$, polifenol $643 \mathrm{ppm}$ dan tingkat penerimaan panelis terhadap aroma, warna, rasa dan tekstur beturut turut 3,$45 ; 2,82 ; 2,91 ; 3,00$ yaitu disukai. Sedangkan pada keripik singkong pada penambahan gambir $0,4 \mathrm{~g} / \mathrm{kg}$ dengan kadar lemak 22,27 \%, kadar polifenol 188 ppm, dan penerimaan panelis terhadap aroma, warna, rasa dan tekstur berturut turut 2,$91 ; 3,15 ; 3,08 ; 2,65$ disukai. Gambir murni dapat diaplikasikan dengan baik pada pinyaram, namun kurang disarankan untuk pemakaian langsung pada minyak pada penggorengan keripik singkong.

\section{Ucapan terima kasih}

Terima kasih kepada Balai Riset dan Standardisasi Industri Padang yang telah membantu pendanaan sehingga penelitian berjalan dengan lancar. Terima kasih juga disampaikan kepada Bapak Hendri Muchtar yang telah membantu kelancaran penelitian ini.

\section{Daftar pustaka}

Aditya, M., Ariyanti, P.R., 2016. Manfaat gambir (Uncaria gambir Roxb) sebagai antioksidan benefits of gambir as antioxidant. Majority 5, 129-133.

Aminah, S., 2010. Bilangan peroksida minyak goreng curah dan sifat organoleptik tempe pada pengulangan penggorengan. J. Pangan dan Gizi 01, 7-14.

Arpi, N., 2014. Kombinasi antioksidan alami $\alpha$-tokoferol dengan asam askorbat dan antioksidan sintetis BHA dengan BHT dalam menghambat ketengikan kelapa gongseng giling selama penyimpanan. J. Teknol. dan Ind. Pertan. . Unsyiah 06, 33-38. https://doi.org/ 10.17969/jtipi.v6i2.2064

Brand-Williams, W., Cuvelier, M.E., Berset, C., 1995. Use of a free radical method to evaluate antioxidant activity. LWT - Food Sci. Technol. https://doi.org/ 10.1016/S0023-6438(95)80008-5

Chaovanalikit, A., Wrolstad, R.E., 2004. Total anthocyanins and total phenolics of fresh and processed cherries and their antioxidant properties. J. 
Food Sci. https://doi.org/10.1111/j.1365-2621.2004. tb17858.x

Departemen Kesehatan RI, D.J.P.O. dan M.D.P.O., 2000. Parameter standar umum ekstrak tumbuhan obat.

Failisnur, F., Sofyan, S., Hermianti, W., 2017. Pemanfaatan limbah cair pengempaan gambir untuk pewarnaan kain batik. J. Litbang Ind. 7, 19-28. https://doi.org/10.24960/jli.v7i1.2695.19-28

Gulcin, I., 2012. Antioxidant activity of food constituents: An overview. Arch. Toxicol. https://doi.org/10.1007/s00204-011-0774-2

Hermawan, H., Sari, B.L., Nashrianto, H., 2018. Kadar polifenol dan aktivitas antioksidan ekstrak etil asetat dan metanol buah ketapang (Terminalia catappa L.). J. Online Mhs. Bid. Farm.

Kamsina, K., Firdausni, F., 2018. Pengaruh penggunaan ekstrak gambir sebagai antimikroba terhadap mutu dan ketahanan simpan cake bengkuang (Pachyrhizus erosus). J. Litbang Ind. 8, 111-117. https://doi.org/10.24960/jli.v8i2.4329.111-117

Kasim, A., Mutiar, S., 2012. Aplikasi gambir sebagai bahan penyamak kulit melalui penerapan penyamakan kombinasi. J. Litbang Ind. 2, 55-62. https://doi.org/10.24960/jli.v2i2.600.55-62

Katrin, Bendra, A., 2015. Aktivitas antioksidan ekstrak, fraksi dan golongan senyawa kimia daun Premna oblongata Miq, in: Pharm Sci Res. pp. 21-31.

Khairunnisa, Z., Wardana, A.S., Rauf, R., 2019. Angka asam dan peroksida minyak jelantah dari penggorengan lele secara berulang. J. Kesehat. 12, 81-90.

Kresnawaty, I., Zainuddin, A., 2009. Aktivitas antioksidan dan antibakteri dari derivat metil ekstrak etanol daun gambir (Uncaria gambir). J. Penelit. Tanam. Ind. 15, 145-151. https://doi.org/10.21082/ littri.v15n4.2009.\%p

Lamusu, D., 2018. Uji organoleptik jalangkote ubi jalar ungu (Ipomoea batatas L) sebagai upaya diversifikasi pangan. J. Pengolah. Pangan 3, 9-15.

Martiningsih, N.W., Widana, G.A.B., Kristiyanti, P.L.P., 2016. Skrining fitokimia dan uji aktivitas antioksidan ekstrak etanol daun Matoa (Pometia pinnata) dengan metode DPPH. Pros. Semin. Nas. MIPA 0, 332-338.

Muchtar, H., Yeni, G., Hermianti, W., Diza, Y., 2010. Pembuatan konsentrat polifenol gambir (Uncaria gambir roxb) sebagai bahan antioksidan pangan. J. Ris. Ind. 4, 71-82.

Rauf, R., Santoso, U., Suparmo, S., 2010. Aktivitas penangkapan radikal DPPH ekstrak gambir (Uncaria gambir Roxb.), Agritech.

Regina, A., Maimunah, M., Yovita, L., 2008. Penentuan aktivitas antioksidan, kadar fenolat total dan likopen pada buah tomat (Solanum lycopersicum L). J. Sains dan Teknol. Farm.

Rukmini, A., 2007. Regenerasi minyak goreng bekas dengan arang sekam menekan kerusakan organ tubuh, in: Seminar Nasional Teknologi 2007. Universitas Widya Mataram Yogyakarta, pp. 1-9. https://doi.org/ISSN:1978-9777

Yeni, G., Syamsu, K., Mardliyati, E., Muchtar, H., 2017. Penentuan teknologi proses pembuatan gambir murni dan katekin terstandar dari gambir asalan. J. Litbang Ind. 7, 1-10. https://doi.org/10.24960/ .v7i1.2846.110 